This item was submitted to Loughborough's Research Repository by the author.

Items in Figshare are protected by copyright, with all rights reserved, unless otherwise indicated.

\title{
Overcoming the translational challenges of the effective administration and delivery of cells
}

PLEASE CITE THE PUBLISHED VERSION

http://dx.doi.org/10.1016/j.jcyt.2015.03.599

\section{PUBLISHER}

(c) Elsevier Inc.

\section{VERSION}

AM (Accepted Manuscript)

\section{PUBLISHER STATEMENT}

This work is made available according to the conditions of the Creative Commons Attribution-NonCommercialNoDerivatives 4.0 International (CC BY-NC-ND 4.0) licence. Full details of this licence are available at: https://creativecommons.org/licenses/by-nc-nd/4.0/

\section{LICENCE}

CC BY-NC-ND 4.0

\section{REPOSITORY RECORD}

Lyness, Alexander M., Nick Medcalf, and David J. Williams. 2019. "Overcoming the Translational Challenges of the Effective Administration and Delivery of Cells". figshare. https://hdl.handle.net/2134/18486. 
Cytotherapy - Volume 17, Issue 6, Supplement, June 2015, Pages S83-S84

\section{OVERCOMING THE TRANSLATIONAL CHALLENGES OF THE EFFECTIVE ADMINISTRATION AND DELIVERY OF CELLS}

DR ALEX LYNESS

PROF DAVID J WILLIAMS

PROF NICHOLAS MEDCALF

CENTRE for BIOLOGICAL ENGINEERING, LOUghBorough UNIVERSITY, LOUGHBOROUGH, LE11 3TU, UK

Of the few cell-based therapies widely available today the most mature are the treatment of bloodborne cancers and wound healing. The routes of administration for these applications are well understood and a great deal of research has resolved the many biological, pharmacological and engineering challenges associated with the delivery of cells by these methods.

These delivery methods are only suitable for a small proportion of the possible cell therapies. Many other treatments under development for illnesses that affect organs - such as diabetes, dermatological conditions and degenerative diseases - require more complex tools and methods to ensure cells are efficiently and effectively delivered to structures such as the pancreas, skin and brain. Injuries to musculoskeletal tissues such as cartilage, intra-vertebral disc and bone may be more easily accessed; however, they present different challenges, as the methods must not reduce the long-term mechanical function of the tissue the treatment is attempting to repair.

Oversights can occur due to the reliance on existing and often unsuitable pre-clinical models and experimental methods and data that cannot be readily translated into the clinic. Different cell types and their behaviours will also lead to complications, so too will engineering challenges such as dosing accuracy, delivery to the appropriate site, engraftment and cell viability after shear and thermal stresses.

The delivery method and device used should be considered a crucial part of the cell therapy as a whole. Many companies in regenerative medicine have designed their own delivery device often in series, not in parallel, with the development of their product. As more treatments get closer to clinic many more different devices will be required, thus presenting opportunities for those who understand the generic delivery challenges in the field. 